\title{
The Effect of Science Process Skills Teaching Approach on Secondary School Students' Achievement in Chemistry in Nyando District, Kenya
}

\author{
Hesbon E. Abungu \\ Mark 1.O. Okere \\ Samuel W. Wachanga \\ Department of Curriculum, Instruction and Educational \\ Management Egerton University, Kenya
}

Doi:10.5901/jesr.2014.v4n6p359

\begin{abstract}
Science process skills are central to the acquisition of scientific knowledge which is useful in solving problems in society. In Kenya, students' achievement in chemistry in the Kenya Certificate of Secondary Education (KCSE) is generally low. The low performance could probably be attributed to lack of exposure to science process skills. This study investigated the effect of science process skills teaching approach (SPSTA) on students' achievement in chemistry. Solomon Four Group Quasiexperimental design was employed. Purposive sampling was used in selecting four district secondary schools having equal number of boys and girls. The sample size was 153 Form Three students. The Form Three classes were randomly assigned to two experimental and two control groups. The study covered two topics selected from the KCSE Chemistry syllabus namely, Volumetric analysis (Titration) and Qualitative analysis. Chemistry Achievement Test (CAT) consisting of simple calculations, True and False items, and Fill in blanks were used as a pre-test. After the administration of treatment, which lasted five weeks, the same test was administered to the four groups as a post-test. The reliability coefficient of the CAT estimated using KuderRichardson (K-R21) formula was equal to 0.88. The data were analyzed using descriptive statistics, t-test, ANOVA and ANCOVA. Hypotheses were tested at $\alpha=0.05$ level of significance. The results revealed that SPSTA had a significant effect on students' achievement in Chemistry. The outcome of this study may provide an insight for designing instructional strategies that aim to enhance students' performance and contribute to the improvement of teaching and learning of chemistry in secondary schools.
\end{abstract}

Keywords: Science process skill, Teaching Approach, Achievement, Chemistry

\section{Introduction}

The need to include science education in the secondary school curriculum is mainly to enable students develop scientific knowledge, skills and positive attitudes towards science and technology. This would enable them understand the role and value of science and technology in society and the interaction between science, technology and society. Science education creates awareness on the effect of scientific knowledge in everyday life, for example, its applications in society, the management and conservation of the environment, the utilization of resources and production of goods (KIE, 2002). The other reason for having science education at secondary school is to address the challenges of scientific literacy, so that students are encouraged to understand the scientific enterprise and how to benefit from it (Collette \& Chiapetta, 1984).

Science as a practical subject provides students with an opportunity to interact with science process skills that can be used to solve problems in everyday life and contribute to national development. Science process skills are activities, which students carry out in scientific investigations to enable the acquisition of scientific knowledge and skills. The importance of teaching science process skills is to allow students to describe objects and events, ask questions, construct explanations, test those explanations against current scientific knowledge and communicate their ideas to others (Opara, 2011). Science process skills enable students experience hands-on engagement with science materials when solving problems using practical approaches. The emphasis on process-based activities in science lessons cannot be doubted, as this is clearly evident in the objectives and instructional programmes in science subjects at the secondary schools. The proponents of process-based approach uphold the teaching of process-skills and advocate for the skills to be developed through experimenting (ILEA, 1987). Raven and Calvey (1977) investigated the effect of a process- 
oriented science programme with the elementary school children on the achievement of Piaget's operative comprehension. The findings of the study showed that eighth grade students achieved higher scores on operative items than the eighth grade students in a more traditional science programme. The interaction with process-skills is evident throughout the students' daily lives and also in science lessons when they engage in practical activities. The activities carried out by the students under this framework will enable them to practice and utilize process-skills. This set of intellectual abilities is referred to as science process skills, which scientists use (Bentley, Ebert \& Ebert, 2007).

Besides promoting the acquisition of the process-skills, practical work in science facilitate the necessary learning environments such as active participation, integration to life and meaningful learning (Karamustafaoglu, 2011). There are quite a number of science process skills provided for in the secondary school chemistry syllabus. However, this paper focused on four selected process skills commonly practiced in the Chemistry lessons and tested by KCSE Chemistry practical paper; namely, observing, measuring, recording and interpreting.

\subsection{Observing}

The process-skill of observation involves the use of ones senses to perceive objects and events; their properties and behavior. It requires that the students pay close attention to some aspects of what is being observed. An observation entails the description of phenomena, for example, during titration experiment the students would be required to observe and state the colour change of the substance formed in the conical flask, measure and record the volume of titre used to effect the change. In this respect, observation as a process-skill would bring into play other process-skills. In Chemistry lessons, students should be taught to observe closely and make relevant observations. Kempa (1986) reiterates that observation skill is relevant to the practice of science and is useful to the students in their everyday life. Practical activity in Chemistry lessons could be utilized to improve students' powers of observation by using all the senses to make deliberate and selective observations. The secondary school Chemistry syllabus emphasizes the practice of observation skill not simply for their immediate appeal and the wonder of excitement that they bring to the classroom setting but also to enable the students develop science process skill of observation.

The KCSE Chemistry Syllabus highlights the making of accurate observations during class experiments as one of the major objectives of practical work in Chemistry (KIE, 2002). 'O' level Chemistry syllabuses from other countries, for example, the UK put emphasis on the development of observation process-skill as a major reason for doing Chemistry experiments, the Northern Examination Association Syllabus, the Midland Examining Group Syllabus and the London and East Anglia Examining Group (UK) emphasize the practice of observation skill in Chemistry practical sessions (Gott, 1987). They argue that observation process-skill is a fundamental tool that would be required by the students of Chemistry to gain scientific knowledge and survive in technological and everyday life. In this study, students were asked to observe and describe the reactions taking place during acid-base titration and identify the cations and anions in the qualitative analysis experiment.

\subsection{Measuring}

Most students are introduced to elementary measurement through science and mathematics lessons in the primary school, for instance, measuring length, weights, time, temperatures and volumes of substances (Kellington et al, 1980; Bentley et al, 2007). But when they enter secondary school, this skill is built on through the use of more accurate tools. It is at this stage that students come in contact with measuring instruments in a practical situation. In chemistry lessons at secondary school level, the students' abilities to measure are extended further through a variety of experiments. The tasks set require them to read and use instruments and apparatus, for example, weighing a sample of substance using a balance and/or measuring the volume of a substance in a burette (KIE, 2002). The tasks of this nature are very common in KCSE Chemistry practical examinations (KNEC, 2006; KNEC, 2007; KNEC, 2008; KNEC 2010). Therefore, the main objective of including such tasks in the chemistry secondary school syllabus is to enable students develop the processskill of measuring and eventually prepare for KCSE chemistry examination.

\subsection{Recording}

Most practical work in Chemistry involves recording observations, measurements, drawing experimental set-ups and tabulating readings in titration and rate of reaction experiments. Recording is a science process-skill that represents a view of presenting experimental results, which can be in a table-form, written form, and graphical manner and through 
drawing. The students' ability to communicate the results of an experiment is of great importance. Okere (1996) underscored the foregoing statement by suggesting that tabulation of results could make it easier for a student to recognize a pattern in the data recorded and also an average value of the quantity measured can be obtained from a set of two or more readings made. The records made by the students reflect the accuracy of the observed results.

\subsection{Interpreting}

Interpretation is an example of a cognitive skill, which enables students to make sense of data obtained from a practical test. There are usually many interpretations made from data obtained from an experiment, some of which may be correct while others could be incorrect. However, interpretations are statements made from observations; some of these may be influenced by theoretical paradigms. In Chemistry, students interpret data using experience and information learnt during practical work to enable them explain what is observed (Tomkins \& Tunncliffe, 2001).

\subsection{Science Process Skills Teaching Approach (SPSTA)}

SPSTA is important for teaching science subjects in schools since it contributes to the understanding of abstract concepts in science, which would remain implicit if taught theoretically (Hodson, 1990). The practical activities carried out by students in class also motivate and prepare them for the pursuit of science related courses at higher levels. Hodson suggested that when students' interests are captured through hands-on activities, the consequence is that they will do better in the subject. Jenkins (1989) reinforced the foregoing statement by arguing that scientific knowledge presented through practical activities can be appealing and accessible to students. Hodson (1990) reported that process skills could aid the understanding of the theoretical scientific knowledge if practical learning opportunities were put in place. After acquiring practical science process skills students may be able to tackle practical tasks in the informal sector and industry. The prospects of involving students in science practical activities include improving the mastery of science process skills and enhancing the ability to understand the scientific concepts. The selected science process skills investigated in this study were observing, measuring, recording and interpreting.

Science education progammes throughout the world have given tremendous opportunity to young scientists in training to acquire knowledge and skills for solving problems. At the global level, there is emphasis on the development of science process skills and scientific knowledge among young children as the major objectives of science education (Adeyemi, 1990; Urevbu, 1990). Attempts have been made to re-examine the role of process skills in science teaching in the secondary schools. For example, the 1996 issue of International Journal of Science Education devoted most of its articles on the role of the school laboratory to science teaching (Donnelly, 1998). A greater portion of the Handbook of Research in Science Teaching highlights research on this topic (White, 1996). In England and Wales, Brotherton and Preece (1996) explored the effects of teaching science with a special emphasis on process skills. For example, the Cognitive Acceleration through Science Education (CASE) project provided evidence that having science process skills in science lesson activities based on Piagetian formal reasoning patterns lead to short term boost to cognitive achievement (Adey and Shayer, 1993). The American Association for the Advancement of Science (AAAS, 1967) study incorporated basic and integrated process skills in an intervention and the outcome revealed that enhanced science process skills in science lessons, raised the level of performance in science by boys. The findings of an investigation carried out by Preece and Brotherton (1997) on the effect of teaching science with an emphasis on process skills for promoting performance in science showed a positive result. Nyakan (2008) investigated the effect of science process skills instructional approach on form two secondary school students' achievement in physics in Kenya. He found that students who learned through science process skills instructional approach attained higher mean scores in physics than those who learned through traditional instructional approach after eight weeks intervention. These findings support interventions that involve process skills teaching strategy. In the 1960s and the early 1970s most of the science curriculum developments promoted hands-on practical work as an enjoyable and effective form of learning (Hodson, 1990). The science 5-16 (Age group) Statement of policy (UK) recommended that science courses should provide appropriate opportunities for students to make observations, measurements and carry out experiments (DES, 1985). In the 1990s, the National Curriculum was a major government sponsored initiative in the UK, which was seen to emphasize the role of laboratory work in secondary schools. Science educators view laboratory activities as central in the science curriculum practices and have suggested that many benefits accrue from engaging students in science laboratory activities (Hofstein \& Lunetta, 1982; 2004; Tobin, 1990; Hodson, 1993; Lunetta, 1998; Hofstein, 2004; Lunetta et al., 2007). 
In Kenya, the secondary school curriculum has had a long history of practical based approach to teaching science. The most recent initiative is the 8.4.4 curriculum (Omulandu \& Shiundu, 1992). For example, the 8. 4.4 secondary school science syllabus places emphasis on practical work (KIE, 2002). The need for students to engage in science process skills is clearly stated in the objectives of teaching Chemistry in secondary schools (KIE), Strengthening of Mathematics and Science in Secondary Education (SMASSE) programs (Changeiywo, 2000). The secondary schools annual science congress and the emphasis put on students' projects in schools are initiatives intended to enable students acquire science process skills. The instructional methods adopted in science lessons are intended to promote problem solving activities, project work and use of local materials. The Kenya Vision 2030 proposes application of science and technology to raise productivity and accelerate economic development, which is intended to enable Kenya join the newly industrializing countries (GOK, 2007). SPSTA in secondary schools in Kenya is intended to facilitate the acquisition of skills and application of scientific knowledge necessary for the economic take-off in the $21^{\text {st }}$ century. The activities under this framework focus on a wide range of skills and processes and attest to the importance of experimental work in the secondary schools science. If all the secondary schools take up the challenge seriously then most of the graduates will be equipped with process skills necessary for technological development of this nation.

The present Kenyan secondary school curriculum is practical oriented and broad-based. It is designed to offer varied experiences to the students, which may lead to an all-round individual. It aims at preparing children for vocational and commercial entreprises and also for the fulfillment of emotional, social and personality attributes (KIE, 2002). Okere (1986) observed that students who complete the secondary school education successfully should have attained appropriate psychomotor and affective skills. Besides, the students who terminate their education at secondary school level will have acquired adequate knowledge and skills to make them useful members of the society. Okere (1996) argues that the most important means of achieving the foregoing attributes is through the school curriculum, which incorporates practical activities in the learning of science. The view is supported by Maundu, Sambili and Muthui (1998) who stated that a scientist must intellectually be able to solve problems in terms of cause and effect relationships and carry out activities that involve psychomotor skills.

Chemistry in particular, takes up a very significant place in the secondary school curriculum because of its applications in everyday life and the role it plays in enabling students to develop intellectual and practical skills. Haines (1992) suggests that through practical activities in Chemistry, students are able to develop science process skills necessary for solving problems in real life situations. The application of chemical knowledge has improved the life of mankind in the area of medicine, agriculture, transport and food industry (Okere, 1996). It also enables students to explore the world by understanding the chemical phenomena, procedures and its investigative nature.

However, most students in secondary schools in Kenya find chemistry concepts difficult to understand as compared to other science subjects, this is reflected in the low scores obtained in KCSE by the candidates (KNEC, 2011), see Tables 1 and 2.

Table 1: The KCSE Chemistry, Physics, Biology National overall Performance (2002-2010)

\begin{tabular}{llll}
\multicolumn{4}{l}{ Percentage Mean Score } \\
Year & Chemistry & Physics & Biology \\
\hline 2002 & 18.0 & 22.0 & 23.0 \\
2003 & 19.6 & 23.0 & 26.0 \\
2004 & 20.8 & 25.1 & 30.6 \\
2005 & 20.0 & 25.5 & 25.9 \\
2006 & 24.9 & 40.3 & 27.4 \\
2007 & 25.4 & 41.3 & 41.9 \\
2008 & 22.7 & 36.7 & 30.3 \\
2009 & 19.1 & 31.3 & 27.1 \\
2010 & 24.9 & 35.1 & 29.2 \\
\hline
\end{tabular}

Source: - KNEC (2003- 2011).

In the period 2002-2005, the average performance in Chemistry at KCSE was about 19.6\%, which is lower than Physics (24\%) and Biology (26.4\%) during the same period. However, there was an improvement in performance in Chemistry in the year 2006 and 2007 though still dismal as compared to performance in Physics and Biology, this declined in 2008 and 2009.

Table 2 shows the candidates performance in the practical papers in Chemistry, Physics and Biology. The three subjects are compared because they are closely related and belong to one major area of knowledge with practical 
components in the curriculum.

Table 2: Chemistry, Physics, Biology Practical Papers

\begin{tabular}{llll}
\multicolumn{4}{c}{ Percentage Mean Score } \\
\hline Year & Chemistry & Physics & Biology \\
\hline 2002 & 30.6 & 32.6 & 21.8 \\
2003 & 36.4 & 40.4 & 25.9 \\
2004 & 35.5 & 56.3 & 28.8 \\
2005 & 33.9 & 53.1 & 22.3 \\
2006 & 28.7 & 52.2 & 29.0 \\
2007 & 29.7 & 64.6 & 54.2 \\
2008 & 28.7 & 60.0 & 43.3 \\
2009 & 27.2 & 38.1 & 39.7 \\
2010 & 37.2 & 56.0 & 46.1 \\
\hline
\end{tabular}

Source: - KNEC 2003-2011)

The average performance in Chemistry practical paper during the period 2002-2005 was slightly better than the performance in biology practical paper but lower than the performance in physics practical paper (Table 2). While the performance in physics and biology practical papers improved substantially in the year 2006 and 2008, the performance in Chemistry practical paper remained low. The low percentage mean score of candidates in Chemistry practical paper (an average of 32\%) may have substantially contributed to the overall low achievement in Chemistry.

In Nyando District the students' performance in Chemistry is equally poor. The students mean point/grade in Chemistry, Physics and Biology in KCSE in the district between the years 2002 and 2008 is shown in Table 3.

Table 3: The KCSE Science Subjects' Performance in Nyando District.

\begin{tabular}{ccccccc}
\hline Subjects & Chemistry & \multicolumn{3}{c}{ Physics } & \multicolumn{2}{c}{ Biology } \\
\hline Year & Total enrolment & Mean point/Grade & Total enrolment & Mean point/Grade & Total enrolment & Mean point/Grade \\
\hline 2002 & 1953 & 4.533 & 510 & 5.611 & 1833 & 5.214 \\
2003 & 2181 & 4.153 & 585 & 5.435 & 2000 & 4.995 \\
2004 & 2297 & 5.138 & 633 & 6.005 & 2117 & 6.816 \\
2005 & 2643 & 4.915 & 708 & 6.154 & 2464 & 5.680 \\
2006 & 2572 & 4.511 & 779 & 6.190 & 2367 & 6.190 \\
2007 & 2758 & 4.637 & 928 & 6.179 & 2534 & 6.139 \\
2008 & 3371 & 4.411 & 1074 & 6.415 & 3150 & 5.751 \\
\hline
\end{tabular}

Interpretation of Mean Point with Equivalent Grade

$A=12, A-=11, B+=10, B=9, B-=8, C+=7, C=6, C-=5, D+=4, D=3, D-=2, E=1$.

Source: Nyando District KCSE results analysis (2002-2008)

The district mean point index of 4.53 and 4.15 in Chemistry is equivalent to D+ grade in 2002 and 2003 respectively. There was a slight improvement in the mean grade in 2004 of C-. This reverted to a mean grade D+ in the subsequent years 2005, 2006, 2007and 2008. The low mean grade obtained in Chemistry by candidates in Nyando District shows that the achievement in the subject is poor and this prompted the investigation on the methods of teaching Chemistry employed by the teachers in the district. Therefore the main objective of this study was to find whether science process skills teaching approach (SPSTA) would be a more suitable method of teaching Chemistry in improving the students' performance.

\section{Purpose of the Study}

The purpose of the study was to determine the effect of science process skills teaching approach on secondary school students' achievement in Chemistry. 


\section{Null Hypothesis}

There is no statistically significant difference in chemistry achievement of students taught through SPSTA and that of those who are not exposed to it.

\section{Methodology}

The study involved quasi-experimental research using the Solomon's Four-Group Non-Equivalent Control Group Design (Gall, Borg \& Gall, 1996). The design used is given in figure 1.

Figure1: Solomon's Four-Group, Non-equivalent Control Group design

\begin{tabular}{lrrrl} 
Group I & $0_{1}$ & $\mathrm{X}$ & $0_{2}$ & Experimental group \\
\hline Group II & $0_{3}$ & & $0_{4}$ & Control group \\
\hline Group III & $\mathrm{X}$ & $0_{5}$ & Experimental group \\
\hdashline Group IV & & & $0_{6}$ & Control group
\end{tabular}

Key: -Pre-tests $\mathrm{O}_{1}$ and $\mathrm{O}_{3}$, Post-tests $\mathrm{O}_{2}, \mathrm{O}_{4}, \mathrm{O}_{5}$ and $\mathrm{O}_{6}$ Treatment $\mathrm{X}$ Control group equivalent.

Source: Cohen and Manion (1994), Gall, Borg and Gall (1996) and Wiersma and Jurs (2005).

The target population for the study was 3500 students in Form Three classes in the secondary schools in Nyando District. However, the accessible population was composed of Form Three students in sixty-three district schools. The sample consisted of Form Three students drawn from four district schools purposively sampled. The four schools were located far apart from each other to eliminate diffusion of information from the experimental groups to the control groups. The students admitted to these schools have comparable academic abilities arising from the selection process after KCPE. The schools were randomly assigned to the experimental and control groups. Each school provided a Form Three class to participate in the study but in cases where a school operates double or multi-streams, simple random sampling was used to pick one stream. The total number of students who took part in the study was one hundred and fifty three (153), with each school having approximately forty students. This provided a reasonable sample size whose findings may easily reproduce the salient characteristics of the accessible population to an acceptable level (Mugenda \& Mugenda, 1999). The optimum sample size required for each participating group in an experimental research as recommended by Coolican (1999), Gall, Borg and Gall (1996) is thirty respondents. This number compared very well with the sample size employed in this study. The recommended class size for secondary schools in Kenya is approximately forty students.

\subsection{Intervention}

The researcher visited the sample schools to brief the Principals and the Chemistry teachers on the nature and purpose of the study. An induction course was offered to the Chemistry teachers who administered treatment to the students in the experimental groups for one day.

Table 4 shows the number of schools and students that participated in each group as outlined in Figure 1.

Table 4: Assignment of sample schools and students to the experimental and control groups

\begin{tabular}{clcc}
\hline Groups & & School & Students \\
\hline I & Experimental Group 1 (with treatment) & 1 & 50 \\
II & Control Group 1 (without treatment) & 1 & 30 \\
III & Experimental Group 2 (with treatment but not pre-tested) & 1 & 40 \\
IV & Control Group 2 (without treatment and pre-test) & 1 & 33 \\
Total & & 4 & 153 \\
\hline
\end{tabular}

The experimental groups received treatment conducted by the chemistry teachers for a period of five weeks. Four 
sessions of practical work were organized, each session lasting eighty minutes. The students carried out experiments on the following content areas.

(i) Volumetric analysis (Titration of a base with an acid)

(ii) Qualitative analysis (detection of cations and anions)

During the practical sessions, the students were divided into five groups with about eight students each. Before the beginning of each session, the teacher informed and instructed the students on the objectives and procedures of working. The materials, apparatus and instructions for the experiment for each practical session were provided. The students did all the activities and the teacher visited the groups and posed guiding questions intended to lead them to an appropriate direction. Teachers in the control groups were asked to cover the same topics during the period of study but were free to follow their regular/conventional methods of teaching Chemistry in their schools.

Chemistry Achievement Test (CAT) was developed and used as a pre-test and post-test, this was mainly to determine students' knowledge in Chemistry with respect to selected topics. It had 60 items consisting of simple calculations, True and False, and Fill in blanks. It covered two topics namely, Volumetric analysis (Titration) and Qualitative analysis selected from Form Three KCSE Chemistry syllabus. After an instructional intervention, the same CAT was reorganized by shuffling the items and then administered to the experimental and control groups as post-test. The test was scored on the basis of correct or incorrect responses. Each correct and incorrect response was scored one and zero marks respectively. Four experts comprising senior members of the department of Curriculum, Instruction and Educational Management, Egerton University and two examiners of Chemistry registered with Kenya National Examination Council (KNEC) validated the Chemistry knowledge. The exercise was to ascertain the content validity of the items used in the instrument. The outcome from pilot testing was used to estimate the reliability of the instrument and also to find out the content validity of the items in order to establish if they were functional. Kuder-Richardson 21 formula (K-R21) was used to calculate the reliability coefficient of the CAT instrument. The K-R21 was used because the test items were scored dichotomously and were of equal difficulty level (Wiersma \& Jurs, 2005; Bailey, 1982). After the application of treatment, the discrimination indices, facility value of the items were calculated and those found to be having a discrimination index below 0.20 were discarded from the test. The reliability coefficient (K-R21) of the achievement test was 0.88. Data were analysed by t-test, ANOVA and ANCOVA. Pre-test results were used as a covariate.

\section{Results}

\subsection{Pre-Test Results}

Table 5 shows the t-test of the Pre-test mean scores on CAT for Experimental Group 1 and Control Group 1.

Table 5: Independent Samples t-test of the Pre-test Scores on CAT

\begin{tabular}{clcccccc}
\hline Variable & Groups & N & Mean & Std. Deviation & df & T & Sig. (2-tailed) \\
\hline \multirow{2}{*}{ CAT } & Experimental Group 1 & 50 & 43 & 16.00 & 78 & 5.03 & .000 \\
& Control Group 1 & 30 & 26 & 14.00 & & & \\
\hline
\end{tabular}

$\mathrm{t}$ cal $=5.03, \mathrm{t}$ crit $=2.00, \mathrm{df}=78, \mathrm{p}<0.05$

The results of the pre-test showed that students in Experimental Group 1 had a higher mean score than those in Control Group 1. There is statistically significant difference between the mean scores of the two groups $t(78)=5.03, p<0.05$; hence the groups were treated as unequal. This is an indication that the students in Experimental Group 1 and Control Group 1 were not equal in chemistry ability at the starting point. The lack of similarity in academic ability exhibited by the two groups could possibly be due to the selection of the schools, however, the KCPE mean scores for the students in the two groups and the performance of the two schools in the KCSE in the previous years were more or less the equal.

\subsection{Post-test Results}

Table 6 shows the CAT post-test mean scores obtained by the students when the four groups were compared. This was mainly to find out if there are differences in the mean scores and the extent of dispersions of each group. 
Table 6: CAT Post-test Mean Scores Obtained by the Students in the Four Groups

\begin{tabular}{|c|c|c|c|c|}
\hline & $\mathrm{N}$ & Mean & Std. Deviation & Std. Error \\
\hline Experimental Group 1 & 50 & 58.77 & 11.19 & 1.58 \\
\hline Experimental Group 2 & 40 & 44.59 & 13.56 & 2.14 \\
\hline Control Group 1 & 30 & 33.22 & 13.60 & 2.48 \\
\hline Control Group 2 & 33 & 30.64 & 13.25 & 2.31 \\
\hline Total & 153 & 43.99 & 17.13 & 1.38 \\
\hline
\end{tabular}

Experimental Group 1 registered the highest mean score, followed by Experimental Group 2 then Control Group 1 and lastly Control Group 2. The high scores attained by students in Experimental Groups 1 and 2 could probably be due to the exposure to SPSTA. The gain in mean scores between post-test and pre-test of Experimental Group 1 (treatment) as compared to that of the Control Group 1 (no treatment) was quite large. This was an indication that the treatment had a greater effect on the mean scores as compared to the effect that might have been attributed to the pre-test.

Table 7 shows the data of one-way Analysis of Variance (ANOVA) based on the post-test mean scores on the CAT.

Table 7: One-way Analysis of Variance (ANOVA) of the Post-test Mean Scores on the CAT

\begin{tabular}{lccccc}
\hline & Sum of Squares & df & Mean Square & F & Sig. \\
\hline Between Groups & 20300.91 & 3 & 6766.97 & 41.53 & .000 \\
Within Groups & 24281.23 & 149 & 162.96 & & \\
\multicolumn{1}{c}{ Total } & 44582.14 & 152 & & & \\
\hline
\end{tabular}

Fcal $=41.53 ;$ Fcrit $=2.67 ; p<0.05$

$F(3,149)=41.53, p<0.05$, is statistically significant leading to the rejection of the null hypothesis. Since there was significant difference between the means of the groups; it was necessary to carry out post-hoc comparisons test of CAT mean scores to establish where the differences occurred. The tests were carried out using Scheffe procedure at $p<0.05$ level.

Table 8 shows the results of the Scheffe post-hoc comparisons of CAT mean scores. The Scheffe post-hoc procedure is applicable in situations where the composition of the groups tested is not equal in number.

Table 8: Post Hoc Comparisons of the Post-test of CAT Means for the Four Groups

\begin{tabular}{llccc}
\hline \multirow{2}{*}{ (I) groups } & \multicolumn{1}{c}{ (J) groups } & Mean Difference (I-J) & Std. Error & Sig. \\
\hline \multirow{2}{*}{ Experimental Group 1 } & Experimental Group 2 & $14.18^{*}$ & 2.70 & .000 \\
& Control Group 1 & $25.55^{*}$ & 2.94 & .000 \\
& Control Group 2 & $28.13^{*}$ & 2.87 & .000 \\
Experimental Group 2 & Experimental Group 1 & $-14.18^{*}$ & 2.70 & .000 \\
& Control Group 1 & $11.37^{*}$ & 3.08 & .005 \\
& Control Group 2 & $13.95^{*}$ & 3.00 & .000 \\
Control Group 1 & Experimental Group 1 & $-25.55^{*}$ & 2.94 & .000 \\
& Experimental Group 2 & $-11.37^{*}$ & 3.08 & .005 \\
& Control Group 2 & 2.58 & 3.22 & .886 \\
Control Group 2 & Experimental Group 1 & $-28.13^{*}$ & 2.87 & .000 \\
& Control Group 1 & -2.58 & 3.22 & .886 \\
& Experimental Group 2 & $-13.95^{*}$ & 3.00 & .000 \\
\hline
\end{tabular}

The post-hoc comparisons showed that the mean difference between the Experimental Group 1 and the Control Groups 1 and 2 were statistically significant. Experimental Group 2 also showed statistically significant difference with Control Groups 1 and 2. This was expected if the treatment (SPSTA) had an effect on the students' chemistry achievement. 
Since the Experimental Groups 1 and 2 received treatment, the results of post-hoc comparisons confirmed that SPSTA had a positive effect on students' achievement in chemistry, thus, leading to the rejection of the null hypothesis.

However, since this study engaged non-equivalent control group design, which involved distinct/intact groups in the exercise, by the very nature of the groupings, it is possible that the significant differences shown on the post-test mean scores of the groups could have resulted from the pre-existing group differences other than the treatment effect. Therefore it was necessary to carry out analysis of covariance test (ANCOVA) to adjust the post-test mean scores of the groups using the students' Kenya Certificate of Primary Education (KCPE) and the Pre-test as covariates, in an attempt to reduce the effect of the initial group differences (Coolican, 1999)

Table 9 shows the adjusted CAT post-test mean scores for ANCOVA using KCPE as covariate.

Table 9: Adjusted CAT Post-test Mean Scores for ANCOVA with KCPE as Covariate

\begin{tabular}{lccc}
\hline Groups & $\mathrm{N}$ & Mean & Std. Error \\
\hline Experimental Group1 & 50 & $55.36^{\mathrm{a}}$ & 1.82 \\
Experimental Group2 & 37 & $46.09^{\mathrm{a}}$ & 1.97 \\
Control Group 1 & 30 & $36.00^{\mathrm{a}}$ & 2.24 \\
Control Group 2 & 31 & $32.68^{\mathrm{a}}$ & 2.15 \\
\hline
\end{tabular}

a. Covariates appearing in the model are evaluated at the following values: KCPE covariate $=$ 293.48.

The adjusted CAT post-test mean scores with KCPE as covariate for the four groups are shown in Table 9. When the adjusted CAT post-test mean scores of the experimental groups were compared to those of the control groups, the outcome showed that the groups which received treatment had better mean scores over the control groups despite Control Group 1 being pre-tested. This suggested that the pre-test did not influence the achievement of the students who were pre-tested. In such circumstances the only plausible explanation for the enhanced students' achievement in chemistry was the exposure to SPSTA.

Table 10 shows Analysis of Covariance (ANCOVA) of the post-test CAT mean scores with KCPE scores as covariate.

Table 10: Analysis of Covariance (ANCOVA) of the Post-test Scores on CAT

\begin{tabular}{lccccc}
\hline Source & Sum of Squares & df & Mean Square & $F$ & Sig. \\
\hline KCPE & 3429.22 & 1 & 3429.22 & 24.30 & .000 \\
Groups & 10394.46 & 3 & 3464.82 & 24.55 & .000 \\
Error & 20179.02 & 143 & 141.11 & & \\
Fcal $=$ 24.55; Fcrit $=10.13 ; p<0.05$ & & & &
\end{tabular}

The mean score difference of the groups were statistically significant, $F(3,143)=24.55), p<0.05$. Since there is statistically significant difference between Experimental Group 1 and Control Groups 1 and 2, the same trend is also evident between Experimental Group 2 and Control Groups 1 and 2, it can be deduced that SPSTA had an effect on students' achievement in chemistry. From the results in Table 10, it is also clear that the students' performance in KCPE is also predictive of their subsequent performance. but less than that due to treatment.

Table 11 shows post-hoc pair wise comparisons based on ANCOVA for CAT mean scores for the four groups. 
Table 11: ANCOVA Pair wise Comparisons on CAT Mean Scores for the Four Groups.

\begin{tabular}{llccc}
\hline \multirow{2}{*}{ (I) groups } & \multicolumn{1}{c}{ (J) groups } & Mean Difference (I-J) & Std. Error & Sig. \\
\hline \multirow{3}{*}{ Experimental Group 1 } & Experimental Group 2 & 9.26 & 2.74 & .001 \\
& Control Group 1 & $19.36^{*}$ & 3.02 & .000 \\
& Control Group 2 & $22.68^{*}$ & 2.89 & .000 \\
Experimental Group 2 & Experimental Group 1 & -9.26 & 2.74 & .001 \\
& Control Group 1 & $10.10^{*}$ & 2.94 & .001 \\
& Control Group 2 & $13.42^{*}$ & 2.89 & .000 \\
Control Group 1 & Experimental Group 1 & $-19.36^{*}$ & 3.02 & .000 \\
& Experimental Group 2 & $-10.10^{*}$ & 2.94 & .001 \\
& Control Group 2 & 3.32 & 3.05 & .279 \\
Control Group 2 & Experimental Group 1 & $-22.68^{*}$ & 2.89 & .000 \\
& Experimental Group 2 & $-13.42^{*}$ & 2.89 & .000 \\
& Control Group 1 & -3.32 & 3.05 & .279 \\
\hline
\end{tabular}

Based on estimated marginal means *, The mean difference is significant at $p<0.05$ level.

a. Adjustment for multiple comparisons: Least Significant Difference (equivalent to no adjustment).

The post-hoc pair wise comparisons based on ANCOVA show statistically significant difference between Experimental Group 1 and Control Groups 1 and 2, and the same trend is observed between Experimental Group 2 and Control Groups 1 and 2. This confirms that SPSTA employed in the study had an effect on the students' achievement in chemistry as compared to the regular teaching approach used on the control groups. However, there was observed significant difference in the mean scores between Experimental Group 1 and Experimental Group 2. This could have been occasioned by the fact that the two experimental groups were not equal in abilities at the starting point. Hence, the trend persisted despite the positive effect caused by the treatment on each of the groups.

Table 12 shows the adjusted CAT post-test mean scores for ANCOVA with CAT Pre-test results as covariate.

Table 12: Adjusted CAT Post-test Mean Scores for ANCOVA with Pre-test CAT as Covariate

\begin{tabular}{lccc}
\hline Groups & Mean & Std. Deviation & $\mathrm{N}$ \\
\hline Experimental Group 1 & 58.77 & 11.19 & 50 \\
Control Group 1 & 33.22 & 13.60 & 30 \\
\hline
\end{tabular}

Table 13 shows Analysis of Covariance (ANCOVA) of the CAT post-test mean scores using Pre-test as covariate.

Table 13: Analysis of Covariance of the CAT Post-test Scores (CAT Pre-test as Covariate)

\begin{tabular}{lccccc}
\hline Source & Sum of Squares & Df & Mean Square & F & Sig. \\
\hline CAT (Pre-test) & 5440.65 & 1 & 5440.65 & 69.20 & .000 \\
Groups & 3560.24 & 1 & 3560.24 & 45.28 & .000 \\
Error & 6053.92 & 77 & 78.62 & & \\
\hline
\end{tabular}

The results showed significant difference between the mean scores of Experimental Group 1 and Control Group 1, F (1, $77)=45.28, p<0.05$. Since Experimental Group 1 was taught using SPSTA, it is reasonable to infer that the students who were exposed to SPSTA performed better in chemistry than those who were taught through regular teaching method, therefore, the null hypothesis is rejected. The pre-test had a higher significant contribution to post-test scores compared to the treatment.

\section{Discussion}

After five weeks of science process skills based instruction, the researchers found that the students in the Experimental Groups attained significantly higher scores in chemistry than did the students in the Control Groups. It may be argued that students exposed to the SPSTA had the opportunity to observe, measure, record and interpret data as they were 
involved in the investigative activities. It can further be suggested that the science process skills emphasized in this study might have assisted the experimental groups to perform better in chemistry than the control groups. Studies carried out by Khan et al. (2011); Opara (2011); Wambugu \& Changeiywo (2008); Alexander (2001); Mao \& Chang (1998) and Ertepinar \& Geban (1996) showed that inquiry-based teaching approaches enhanced students' achievement in science subjects, which are in agreement with the findings of this study. Mandor (2002) and Ibe (2004) research findings were also in agreement with the findings of this study by indicating that active participation of the students in science lessons contributed to effective learning. Aktamis and Ergin (2008) carried out a study to investigate the effect of science process skills with elementary school students in Buca District, Turkey, on scientific creativities, academic achievement and attitude towards science, the results were consistent with that of this study that science process skills teaching approach is most effective in enhancing learning of chemistry than regular teaching approach. Tobin (1986) studied the students' tasks involvement and achievement in process-oriented science activities in the elementary schools in Australia and the results indicated that students' engagement in planning and collecting tasks were positively related to achievement. Feyzioglu (2009) carried out a study at the university level and the outcome indicated a positive relationship between science process skills and university students' achievement. Hykle (1994) studied the relationships among gender, science content achievement and science process skills and found that science process skills and the achievement in science were significantly related. A study carried out by Foley and McPhee (2008) in elementary science schools in America showed that students who used hands-on science curriculum had an advantage in achievement over those who followed the traditional textbook curriculum. Foley and McPhee (2008) reported the results of an investigation carried out by Stohr-Hunt (1996) on the effect of hands-on experience and science achievement that showed significant differences in science achievement between the students who engaged in hands-on activities everyday a week and those who never engaged in hands-on activities. Wachanga and Mwangi (2004) investigated the effect of cooperative class experiment (CCE) teaching method on secondary school students' achievement in chemistry and found that students who were taught through CCE achieved significantly higher scores in the CAT than those who were not taught through it. Class experiment method is an example of inquiry -based approach to teaching which emphasizes the use of science process skills. Therefore, process skills may be the desired instructional approach to teaching chemistry. This study gives support to the fact that achievement of students in chemistry could be greatly improved if they are exposed to science process skills teaching approach. However, it is important to note that the success of the approach may depend on the competence, enthusiasm and confidence of the chemistry teacher and the ability of the students in making use of the opportunity provided.

\section{Conclusion}

Science process skills teaching approach facilitates students' achievement in chemistry more than regular teaching approaches.

\section{Implications of the Study}

1. If science process skills instructional strategy is implemented by the chemistry teachers in the secondary school education then there is likelihood of improvement in the performance of chemistry at KCSE.

2. Students' improvement in performance in chemistry may make the subject popular at the secondary school level and this would attract many candidates to opt for science subjects thereby making science oriented courses accessible at professional level and therefore paving the way for advanced technology and industrialization.

3. When students engage in experiments during chemistry lessons, they sharpen their process skills and acquire scientific skills which impact on the overall achievement in chemistry.

4. The policy for science education in secondary schools should reinforce the need to establish and equip science laboratories in all secondary schools to encourage students' involvement in practical related activities.

\section{Recommendations}

1. Chemistry teachers should use science process skills teaching strategy in the teaching of chemistry, particularly at the secondary school level because it can address the poor performance in the subject.

2. The Ministry of Education through KIE, QASO institutions and other professional bodies like Head teachers 
Association, Science Teachers Association, SMASSE should organize workshops, seminars for retraining chemistry teachers on the appropriate utilization of science process skills teaching approach.

3. The institutions offering Teacher Education programmes should train their products to utilize science process skills teaching approach and structure their learning environments that can increase interaction among the learners and enable active participation in the learning process.

4. The chemistry teachers to enhance active participation of secondary school students by organizing frequent practical sessions, provide adequate laboratory facilities and materials for doing experiments and create opportunity for students to share ideas as these activities will engage them effectively in the lesson.

5. The chemistry teachers to structure lessons to provide hands-on activities, with a hope to stimulate students' understanding of science as a process of discovering and acquiring scientific knowledge.

\section{Areas for Further Research}

1. Researchers may use the findings of this study to guide them conduct further research on other science process skills particularly those which relate to integrated skills, for example, experimenting, hypothesizing, determining variables in order to gain more knowledge on the effect of science process skills teaching approach on students' achievement in chemistry.

2. Further work may also be preferred on more demanding scientific process skills such as planning and designing of experiments, as they may have an impact on students' creativity in science.

\section{References}

Adey, P. \& Shayer M.(1993). An exploration of long-term far-transfer effects following an extended intervention program in the high school science curriculum. Journal of Curriculum and Cognition, II (1), 1-29.

Adeyemi, M.A. (1990). Effects of cognitive style school setting and instruction mode on students' attitude to biology. Journal of Nigeria Educational Research, 9 (10), 84-93.

Aktamis, H. \& Ergin O.(2008). The effect of scientific process skills education on students' scientific creativity, science attitudes and academic achievements. Asia-Pacific Forum on Science Learning and Teaching, 9 (1), article 4.

Alexander, M. D. (2001). Inquiry-based methods of instruction in chemistry. http://spacegrant.nmsu.edu/NMSU/2001/d_alexander.pdf

American Association for the Advancement of Science (1967). Science Process Approach, Washington: USA, AAAS.

Bentley, M. L,, Ebert E.S. \& Ebert C. (2007). Teaching constructivist science K- 8: nurturing natural investigators in the standards-based classroom. Crown Press-Sage publications Ltd. Company.

Brotherton , P.N. \& Preece F.W (1996). Teaching science process skills. International Journal of Science Education, 18 (1) 65 -74.

Changeiywo, J. M. (2000). Students' images of science in Kenya: a comparison by gender difference, level of schooling and regional disparities. Unpublished Doctoral Thesis, Egerton University.

Cohen, L. \& Manion L. (1994). Research Methods in Education. Routledge Publishers.

Collette, A.T. \& Chiappetta E.L (1984). Science instruction in the middle and secondary schools. Merrill Publishing Company.

Coolican, H. (1999). Research methods and statistics in psychology. $2^{\text {nd }}$ ed. London: Hodder \& Stoughton.

Department of Education \& Science (1983). Assessment of performance unit (APU) Science in schools Age 15 Report (1). London: The Garden City Press.

Department of Education \& Science (1985). Science 5 - 16: A statement of policy, HMSO.

Donelly, J. (1998) The place of the laboratory in secondary science teaching. International Journal of Science Education, 20 (5), 585596.

Ertepinar, H. \& Geban O. (1996). Effect of instruction supplied with the investigative-oriented laboratory approach on achievement in a science course. Educational Research, 38, 333-341.

Foley, B. J. \& McPhee C. (2008). Students' attitudes towards science in classes using hands-on or textbook based curriculum, American Educational Research Association.

Feyzioglu, B. (2009). An investigation of the relationship between science process skills with efficient laboratory use and science achievement in chemistry education. Journal of Turkish Science Education, 6 (3).

Gott, R. (1987). The assessment of practical investigations in science. School Science Review, March 1987. ASE.

Gall, M.D., Borg, W.R., \& Gall, J.P. (1996). Educational research. An introduction. New York: Longman.

Haines, C. (1992). The role of pupil-centred learning in the teaching of chemistry. In Atlay M; Bennette S., Dutch S., Levinson R., Taylor P. \& West D. (Eds.). Open Chemistry, Milton Keynes: Open University.

Hodson, D. (1990). A critical look of practical work in school science. School Science Review, 71 (256).

Hodson, D. (1993). Re-thinking old ways: towards a more critical approach to practical work in school science. Studies in Science Education, 22, 85-142.

Hofstein, A. \& Lunetta V.N. (1982). The role of laboratory in science teaching: neglected aspects of research, Review of Educational 
Research, 52, 201-217.

Hofstein, A. (2004). The laboratory in chemistry education: thirty years of experience with developments, implementation and evaluation, Chemistry Education Research and Practice, 5, 247-264.

Hykle, J.A. (1994). Interrelationships among cognitive controls, gender science achievement, and science process skills. University of Cincinnati.

Inland Local Education Authority (1987). Science in process. Ten Units and Teachers' Guide, London: Heinemann.

Kellington, S.H.,Mitchell A.C. \& Gillespie A. (1980). How well can your pupils measure? School Science Review, 61 (217). Hatfield: Association for Science Education.

Kempa, R. (1986). Assessment in science. Cambridge University Press.

Khan, M.S., Hussain S., Ali R., Majoka M.I. \& Ramzan M. (2011). Effect of inquiry method on achievement of students in chemistry at secondary school level. International Journal of Academic Research, 3 (1), 955.

Kenya Institute Education (2002). Secondary education syllabus. Vol. 7. Nairobi: Kenya Literature Bureau.

KNEC (2002-2011). Kenya certificate of secondary education examination report. Nairobi: Kenya: Kenya National Examination Council.

Lunetta, V.N. (1998). The school science laboratory: historical perspectives and centers of contemporary teaching. In P. Fensham (Ed.). Developments and dilemmas in science education (pp. 169-188), London, Falmer Press.

Lunetta, V.N., Hofstein A. \& Cloug M. (2007). Learning and teaching in the school science laboratory: An analysis of research, theory and practice. In N. Lederman and S. Abel (Eds.). Handbook of research on science education (pp. 393-441), Mahwah, NJ: Lawrence Erlbaum.

Mandor, A. K. (2002). Effects of constructivist model on acquisition of science process skills among junior secondary students. Unpublished M.Ed. Thesis. Department of Science Education, University of Nigeria, Nsukka.

Mao, S. \& Chan C. (1998). Impacts of an inquiry teaching method on earth science students' learning outcomes and attitudes at the secondary school level. Proceedings National Science Council-ROC (D), 8 (3), 93-101.

Maundu, J.N., Sambili H. J. \& Muthwii S.M. (1998). Biology education: A methodological approach Nairobi: Lectern Publishers .

MOE (2006, 2007). Nyando District Education Office, KCSE results analysis.

MOE (2009). Nyando District Education Office, Secondary schools statistics.

Mugenda, O.M. \& Mugenda A.G. (1999). Research methods: quantitative and qualitative approaches. Nairobi: Acts Press.

Okere, M.I.O. (1996). Physics education: A textbook of methods for physics teaching: Njoro: Egerton University Education Materials Centre.

Okere, M.I.O. (1986). Creativity in physics education, Unpublished PhD Thesis. London University.

Opara, J.A. (2011). Some considerations in achieving effective teaching and learning in science education. Journal of Educational and Social Research, 1 (4).

Preece, F.W. \& Brotherton P.N. (1997). Teaching sciences process skills: long- term effects on science achievement. International Journal of Science Education, 19 (8), 895 - 901.

Raven, R.J. \& Calvey, H. (1977). Achievement on a test of Piaget's operative comprehension as a function of a process-oriented elementary school science program. Science Education, 61 (2), 159-166.

Stohr-Hunt, P.M. (1996). An analysis of frequency of hands-on experience and science achievement. Journal of Research in Science Teaching, 33 (1).

Tobin, K. (1986). Student task involvement and achievement in process-oriented science activities. Science Education, 70 (1), $61-72$.

Tobin, K. G. (1990). Research on science laboratory activities: in pursuit of better questions and answers to improve learning. School Science and Mathematics, 90 (5), 403-418.

Tomkins, S.P. \& Tunnicliffe, S.D. (2001). Looking for ideas: Observation interpretation and hypothesis - making by 12-year old pupils undertaking science investigations. International Journal of Science Education, 23 (8), 791 - 813.

Urevbu, A.O. (1990). Studies in science education: Methodology of science teaching. Binin City. Juland Publishers 150.

Wachanga,S.W. \& Mwangi J.G. (2004). Effects of class experiment teaching method on secondary school students' chemistry achievement in Kenya, Nakuru District. International Education Journal, 5 (1), 26-36.

Wambugu, P.W. \& Changeiywo J. M. (2008). Effects of mastery learning approach on secondary school students' physics achievement. Eurasia Journal of Mathemtics, Science and Technology Education, 4 (3).

White, R.T. (1996). The link between the laboratory and learning. International Journal of Science Education, 18 (7), $761-774$.

Wiersma, W. \& Jurs S.G. (2005). Research methods in education. An introdcution, 8th edition, Boston: Pearson. 
ISSN 2239-978X

ISSN 2240-0524
Journal of Educational and Social Research MCSER Publishing, Rome-Italy
Vol. 4 No. 6 September 2014 